\title{
Is harmonization of retention of title necessary and feasible?
}

\author{
Sylvana Vijn
}

\section{Introduction}

My thesis is about retention of title. I have chosen this subject because Property Law is my favourite area of law, and during my Bachelor Dutch Law I only learned about Dutch Property Law. Writing my thesis about this topic would be a good opportunity to learn more about Property Law in other legal systems. It also gave me the chance to learn how to compare different legal systems and to draw a conclusion from the comparisons. This is something that I never had to deal with before in my Bachelor. Furthermore, writing about this topic would be a challenge for me because I also did not have to deal a lot with European Law, and therefore I did not know much about this area of law. Lastly, it would also be a challenge because I want to look if harmonization is needed and feasible and this is something that I have never looked at before.

I chose to look at four different legal systems; The Netherlands, Germany, France and England. I will look at the rules for retention of title, transfer of ownership, a bona fide purchaser and retention of title, specificatio and retention of title, accessio and retention of title and the legal systems of the Member States. The Bona fide purchaser is dealt with in another section then specificatio and accessio, because acquiring ownership in this way is a form of derivative acquisition of ownership and specificatio and accessio are two forms of original acquisition of ownership. These terms will be discussed in the sections dealing with these subjects. After this I will answer how 3 different cases would be solved according to the different legal systems. These cases will be about; a bona fide purchaser, specificatio and accessio. After answering these cases I will compare the outcomes and on the basis of the outcomes I will determine whether harmonization of retention of title in the European Union is needed. Then I will look at the legal regimes of the four Member States. After this I will determine whether harmonization of retention of title is feasible. 
My two main questions will be:

1. Is harmonization of retention of title in the European Union needed?

2. Is harmonization of retention of title feasible in the European Union?

\section{Retention of title}

\subsection{Retention of title}

When a seller and a buyer conclude a sale of good contract, a few obligations arise under that contract. Two of these obligations are important for retention of title. These are the obligations of the seller to deliver the goods to the buyer and the obligations of the buyer to pay the purchase price to the seller. Nowadays in trade it is normal that the seller already delivers the good to the buyer and that the buyer gets a certain amount of time to pay the purchase price, this is called supplier credit.' The delivery of the good implies the transfer of ownership from the seller to the buyer. [Some legal systems do not even require delivery in order for the transfer of ownership but this will be dealt with in section 3.] If the buyer would pay the purchase price within the determined amount of time, both parties perform their obligations under the contract, and no problems regarding these obligations will arise.

So nowadays in most of the cases the party that performs his obligation first is the seller, which means that the buyer already becomes the legal owner, independent of the fact if payment yet has been made. This of course can be a bit daunting. If the buyer does not pay the price, the seller has to take legal steps in order to get the money that he is entitled to. Another risk is the possibility that a buyer is declared insolvent. In the case that a buyer is declared insolvent the delivered good falls under the insolvency estate of the buyer, because he acquired the ownership, and all the goods acquired by the buyer fall under his insolvency estate. If someone is declared insolvent there are - almost - always more creditors of the buyer. All these creditors have claims and therefore the good could be sold in order to pay claims from other creditors of the buyer. Furthermore, the seller would only get a concurrent claim. This means that there can be other creditors with a higher rank above him. In a lot of insolvency cases there barely is enough money to pay the claims from the creditors with the highest ranks, so this could mean that the seller will never have his claim paid, because there is simply not enough money to pay all the claims.

1 www.kredietverzekeren.nl 'Eigendomsvoorbehoud' 
Well then, if it can be daunting for a seller that the ownership already is transferred, independent of the fact if the buyer paid the purchase price, then why would sellers allow this? And how is it possible that these risks do not hinder trade? The answer to these questions is the possibility for sellers to make a retention of title clause. Retention of title means that the seller retains the ownership of the good, despite of the fact that the requirements for transfer of ownership are met, until a specific condition has been fulfilled by the buyer. [The requirements for the transfer of ownership will be dealt with in section 3.] This condition usually is the payment of the price, but some legal systems also allow retention of title clauses for other conditions. Retention of title is a possibility for the seller to protect himself against non-payment and insolvency of the buyer. The seller retains the legal ownership of the good, so if the buyer does not pay the price, he can claim the possession of the good on the basis of his retention of title. If the buyer would be declared insolvent, and a retention of title has been made, this would mean that the good will not fall in the buyer's insolvency estate because he did not yet acquire the ownership of the good. This means that the good cannot be sold by the liquidator in order to pay the claims from other creditors of the buyer.

However, there are a few ways, other than the fulfilment of the condition by the buyer, by which a retention of title clause can come to an end, these will be dealt with in section 4 and 5 .

\subsection{Retention of title in the Netherlands}

Retention of title is stated in article 92 I of Book 3 of the BW:

Heeft een overeenkomst de strekking dat de een zich de eigendom van een zaak die in de macht van de ander wordt gebracht, voorbehoudt totdat een door de ander verschuldigde prestatie is voldaan, dan wordt hij vermoed zich te verbinden tot overdracht van de zaak aan de ander onder opschortende voorwaarde van voldoening van die prestatie. ${ }^{2}$

The Dutch legislator constructed a retention of title clause as a transfer of ownership under a condition precedent. ${ }^{3}$ This means that the buyer becomes the new owner if he fulfils the

2 'Where a contract is intended to reserve to one party the ownership of a thing which is placed under the control of the other party, until a prestation owed by the latter has been performed, the former is presumed to obligate himself to the transfer of the thing to the latter under a suspensive condition of performance of that prestation'.

3 Rutgers 1999, p. 126. 
condition. The seller has the ownership under a condition subsequent. ${ }^{4}$ This means that he will lose his ownership at the moment that the buyer fulfils the condition. At that moment the ownership will be transferred, if the requirements for transfer are met as well. The fulfilment of the condition does not have retroactive effect. ${ }^{5}$ In the Netherlands a retention of title is not only allowed to get security that payment will be made. It is also allowed for other obligations of the purchaser related to the delivery of the good, this is stated in paragraph 2 of art. 3:92 BW. Art. 3:92 paragraph 1 is ius dispositivum and the seller and the buyer therefore can construct a retention of title clause in a different mode. ${ }^{6}$

\subsection{Retention of title in Germany}

Retention of title is stated in $\S 449$ BGB:

Hat sich der Verkäufer einer beweglichen Sache das Eigentum bis zur Zahlung des Kaufpreises vorbehalten, so ist im Zweifel anzunehmen, dass das Eigentum unter der aufschiebenden Bedingung vollständiger Zahlung des Kaufpreises übertragen wird.?

The German legislator as well constructed a retention of title as a transfer of ownership under a condition precedent. ${ }^{8}$ This means that if the buyer fulfils the condition mentioned in the retention of title clause he will become the owner and before fulfilment of this condition he holds an Antwartschaftsrecht. ${ }^{9}$ The seller, on the other hand, remains the ownership of the good under a condition subsequent. ${ }^{10} \mathrm{He}$ will lose his ownership if the condition is fulfilled. The seller and the buyer can at the latest moment agree on a retention of title clause before the delivery requirement [described in section 3] is fulfilled." But in general the seller and the buyer agree on the retention of title at the same time they conclude the contract of sale. This rule is ius dispositivum and therefore parties are able to change the content of the condition and their duties. ${ }^{12}$

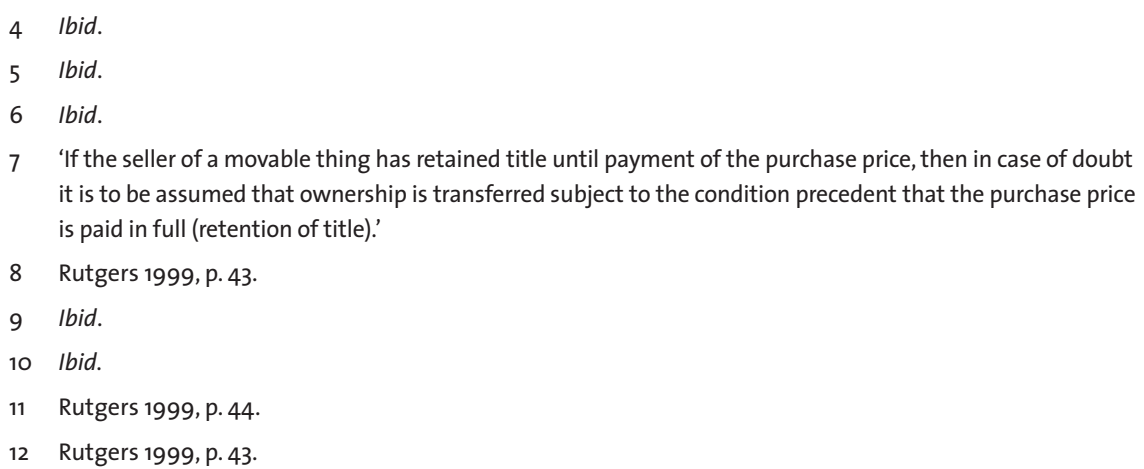




\subsection{Retention of title in France}

Chapter IV of Book IV of the French Civil Code deals with retention of title. The definition is stated in article $2367 \mathrm{CC}$ :

La propriété d'un bien peut être retenue en garantie par l'effet d'une clause de réserve de propriété qui suspend l'effet translatif d'un contrat jusqu'au complet paiement de l'obligation qui en constitue la contrepartie. La propriété ainsi réservée est l'accessoire de la créance dont elle garantit le paiement. ${ }^{13}$

In France the ownership of a good is transferred at the moment of the conclusion of the contract [this will be dealt with in section 3]. That provision is ius dispositivum and therefore parties can agree otherwise. ${ }^{14}$ Early case law determined that a retention of title clause could not be invoked in the buyer's insolvency. ${ }^{15}$ This changed in 1980 when the French legislator determined that a retention of title clause could also be invoked in the buyer's insolvency. ${ }^{16}$ The retention of title clause has to be agreed on in writing.

\subsection{Retention of title in England}

In England retention of title is mentioned in article 19 Sale of Goods Act 1979:

Where there is a contract for the sale of specific goods or where goods are subsequently appropriated to the contract, the seller may, by the terms of the contract or appropriation, reserve the right of disposal of the goods until certain conditions are fulfilled; and in such a case, notwithstanding the delivery of the goods to the buyer, or to a carrier or other bailee or custodier for the purpose of transmission to the buyer, the property in the goods does not pass to the buyer until the conditions imposed by the seller are fulfilled.

According to this article parties can agree that the transfer will be subject to the payment of the purchase price. In 1976 the House of Lords decided on a case which caused a lot

13 Ownership of a property may be retained as security through a clause of retention of title which stays the transferring effect of a contract until payment in full of the obligation which compensates for it. Ownership so retained is the accessory of the debt whose payment it secures.'

Rutgers 1999, p. 61.

15 Omar 1996, p. 1.

16

Rutgers 1999, p. 61. 
of controversy in England, the Romalpa case. ${ }^{17}$ In England a retention of title clause is therefore also sometimes referred to as a Romalpa clause. ${ }^{18}$ This case was so controversy because it gave three new insights about retention of title in England. ${ }^{19}$ First, the operation of retention of title was shifted from the consumer context to the commercial context. Secondly, the seller did not merely reserve title whilst the goods were in the possession of a third party, but he reserved title even though the goods were already in the possession of the buyer. Thirdly, the case illustrated that retention of title could also be used for commodities, raw materials and other less durable personal property.

\section{Transfer of ownership}

This section deals with the requirements for the transfer of ownership in the four chosen Member States. The transferor is the seller whom transfers the ownership and the transferee is the buyer whom becomes the new owner.

\subsection{Different systems}

In European Property Law a distinction can be made between a consensual system and a traditio system on the one hand, and a abstract system and a causal system on the other hand. In the consensual system the conclusion of the contract of sales on its own effects transfer, separate delivery is not required. ${ }^{20}$ This system is inspired by the ideals of the French Revolution, and can be found in a few Member States, such as France, Belgium and England. ${ }^{21}$ In the traditio system a separate delivery method is required..$^{22}$ This system is based on Roman Law and can be found in many Member States, such as The Netherlands and Germany. ${ }^{23}$ The difference between the abstract system and the causal system lies in the importance of a valid title. In the abstract system the realization of the transfer is not dependent on the validity of the title. ${ }^{24}$ In the causal system the realization of the transfer

\footnotetext{
17 Rose 200o, p. 136.

18 http://www.insolvencydirect.bis.gov.uk 'Retention of title'

19 Rose 2000, p. 136.

20 Reehuis 2010, p. 5.

21 Ibid.

22 Ibid.

23 Ibid.

24 Haentjes 2011, p. 3.
} 
is dependent on the validity of the title. ${ }^{25}$ An example of a Member State with an abstract system is Germany, and a Member State with a causal system is the Netherlands.

\subsection{The Netherlands}

According to art. 3:84 Dutch Civil Code there are three requirements for a valid transfer of ownership. There has to be a valid title, delivery and the transferor must have the capacity to dispose his property right.

\section{A Valid Title}

A valid title is for instance a contract of sales, this underlying legal relationship justifies the transfer of ownership. The Netherlands have a causal system, this means that if the title is not valid, the transfer therefore is also not valid. This is an example of codified case law of the Hoge Raad. The Hoge Raad decided in 1950, in Damhof v. De Staat der Nederlanden, that a valid transfer of title requires a valid title. ${ }^{26}$ If the title is declared null and void or avoided the acquirer has never been the owner, because nullification has retroactive effect in the Netherlands according to art. 3:53 BW.

\section{Delivery}

The second requirement for a valid transfer of ownership is delivery. Art. 3:90 BW states that a delivery implies that a transferor must enable the transferee to take possession of the good. The transferor may accomplish this by different modes. First, the transferor may enable the transferee to exercise control over the object, this is stated is art. 3:114 BW. Second, the transferor and the transferee can make a bilateral declaration, according to 3:115 BW. An actual delivery action is not required then. Art. 3:115 BW mentions three possibilities, they are the traditio brevi manu, the traditio longa manu and the traditio constituto possessorio. Traditio brevi manu involves the situation in which the transferee [buyer] already exercises control over the good, on behalf of the transferor [seller] and after the bilateral declaration the transferee will possess the good. ${ }^{27}$ Traditio longa manu involves the situation in which a third person holds a good on behalf of the transferor [seller] and after the bilateral declaration he will hold the good for the transferee [buyer]. ${ }^{28}$ Traditio constituto possessorio involves the situation in which the transferor [seller] is

\footnotetext{
25 Ibid.

26 Rutgers 1999, p. 21.

27 Reehuis 2011, p. 314.

28 Reehuis 2011, p. 315.
} 
the possessor of a good and after the bilateral declaration he will hold the good for the transferee [buyer]. ${ }^{29}$

\section{Capacity}

The third requirement for a valid transfer of ownership is the capacity of the transferor to dispose of his property right. He must be entitled to transfer his ownership in the good. If the transferor is not entitled to do so the ownership will not be transferred. An exception to this rule will be dealt with in section 4 , the bona fide purchaser.

\subsection{Transfer of ownership in Germany}

The requirements for transfer of ownership of a moveable thing in Germany are stated in $\S 929$ BGB, these are a real agreement and delivery. Germany has an abstract system, this means that the title is not valid, this does not affect the validity of the transfer. So if the title is declared null and void or avoided, the acquirer remains the owner of the good.

\section{Real Agreement}

The first requirement for a valid transfer of ownership is a real agreement between the transferor and the transferee. This agreement means that the transferor and the transferee must have consensus that the ownership is transferred from the transferor to the transferee. ${ }^{30}$ This real agreement does not have to be agreed on explicitly nor does it require any set formalities. There are however two other requirements for the real agreement. ${ }^{31}$ The good which is going to be transferred and which is the object of the contract of sales must be determined. Furthermore, the real agreement must exist at the moment of delivery.32

\section{Delivery}

The second requirement for a valid transfer of title is delivery. This requirement can be accomplished by different modes. First, the transferor can provide the transferee with the actual control over the good. ${ }^{33}$ The means that the transferor hands the good over to the transferee. Second, the transferor and the transferee can make an agreement instead of

\footnotetext{
29 Reehuis 2011, p. 313.

30 Rutgers 1999, p. 40.

31 Ibid.

32 Ibid.

33 Ibid.
} 
psychical delivery. ${ }^{34}$ This can be done in three different ways, the traditio brevi manu, the traditio longa manu and the traditio consituto possessorio.

\subsection{Transfer of ownership in France}

In France the ownership is transferred by mere agreement between the transferor and the transferee, this is mentioned in art. 1583 French Civil Code. This rule is ius dispositivum and parties therefore can agree that the ownership is transferred at another moment than at the moment of the conclusion of the contract of sale. 35 So, in France the valid transfer of ownership does not require an delivery, since the ownership is transferred by mere agreement between the transferor and the transferee. I will however describe the different methods of delivery in France stated in art. 1606 CC. First, if the transferor and the transferee did not agree on an alternative arrangement for the transfer of ownership the ownership is transferred by traditio solo consensu. ${ }^{36}$ Second, the transferor can deliver by tradition réele, this means that he hands the good to the transferee. Third, the transferor can deliver by tradition symbolique, this means that he does not hand over the good, but the keys of the building wherein the good is stored. ${ }^{37}$ Fourth, the transferor can deliver by traditio brevi manu. Last, the transferor can deliver by tradition fictive. Tradition fictive has two forms, the traditio solo consensu and the traditio constituto possessorio. ${ }^{38}$

\subsection{Transfer of ownership in England}

In England the transfer of ownership can be accomplished by three methods: sale, delivery and deed. ${ }^{39}$ I will only discuss the transfer by sale and delivery. Art. 17 of the Sale of Goods Act 1979 states that the ownership is transferred from the transferor to the transferee at such time as they intend it to be transferred. If the transferor and the transferee do not agree on such time, art. 18 SAG 1979, which lays down 5 rules, applies. The most important rule is Rule $14^{40}$ This rule states that the ownership is transferred immediately, independent of the fact whether the delivery and payment are postponed. The other rules are for situations in which the transferor still has to do something with the good. In England a good can be

\footnotetext{
34 Ibid.

35 Rutgers 1999, p. 61.

36 Rutgers 1999, p. 58.

37 Rutgers 1999, p. 55

38 lbid.

39 Smith 2006, p. 106.

40 Ibid.
} 
delivered by handing the good over and by a constructive delivery. ${ }^{41}$ Constructive delivery can be done in four ways. ${ }^{42}$ The first way involves the situation in which the transferor already exercised the control over the good before acquiring the ownership. This is the same as traditio brevi manu, but I will not use this definition because it is originated from Roman Private Law and England's law was not influenced by Roman Law. The second way involves the situation in which a third party becomes the holder for the transferee. Again, this is basically the same as traditio longa manu, but because of the aforementioned reason, I will not use this definition. The third way involves the situation in which the transferor will become the holder for the transferee, basically the same as traditio consituto possessorio. The last way involves the situation in which the good is located in a public place and the transferor tells the transferee that he can have the good if he finds it.

\section{Extinction: Bona Fide Purchaser}

The main reason why a retention of title will extinct is because the buyer fulfilled the condition which usually is the payment of the purchase price. This section deals with one other way whereupon a retention of title can extinct. This is the bona fide purchaser. I will look at the rules for this in the four Member States and what the consequence is for a retention of title clause, and therefore for the ownership of the seller.

\subsection{Bone Fide Purchaser}

It is possible that the situation occurs that the buyer already resells the good to a third party, even though the retention of title still exists and the buyer therefore did not yet become the owner. If this third party was not aware of the retention of title and of the fact that the seller did not have the ownership of the good, he can invoke protection if he meets certain requirements. If this third party meets the requirements that are set by the legal system of a specific Member State, we call him a bona fide purchaser. ${ }^{43}$ Acquiring ownership in this way is a form of derivate acquisition. This means that no new ownership is created, but that the ownership passes from one person to another. The requirements that have to be met in order to successfully invoke protection in the four Member States will be discussed here below.

\footnotetext{
41 Smith 2006, p. 107.

42 Ibid.

43 Rutgers 1999, p. 41.
} 


\subsubsection{The Netherlands}

In chapter 1 we saw that the requirements for the transfer of ownership in the Netherlands are a valid title, a method of delivery and that the seller has to have the capacity to dispose of his ownership. In principal, the ownership will only be transferred if these three requirements are met. In the situation in which the buyer resells the good, whereupon a retention of title clause still exists, he cannot meet the capacity requirement, because he did not yet became the owner. I said that in principle the ownership then will not be transferred because the lack of this requirement can be repaired with paragraph 1 of article 3:86 BW. ${ }^{44}$ In order to successfully invoke this article two requirements, stated in this article, have to be met. It must be noted that this article can only repair the lack of capacity, the valid title requirement and the delivery requirement cannot be repaired with this article and therefore must still be fulfilled. ${ }^{45}$ First, the third party must have good faith at the moment of acquisition. This means that the third party did not know that the transferor did not have the capacity to dispose of his ownership, but also that he should not have known it in the given circumstances. ${ }^{46}$ The latter means that if the transferee has doubts about the capacity of the transferor, he must examine his capacity. If he omits to examine this he cannot invoke the protection from art. 3:86 paragraph $1 \mathrm{BW}$. Second, the acquisition of ownership must not be obtained without performing a duty, which is payment of the price. Article 3:87 paragraph $1 \mathrm{BW}$ adds another requirement. 47 If the third party is asked who sold the good to him within 3 years after the acquisition of the good, he must provide sufficient information about the person from whom he bought the good. If he does not fulfil this obligation he cannot invoke the protection from article 3:86 paragraph $1 \mathrm{BW}$. A last remark should be made to the forms of delivery. If the original owner sells a good to someone under a retention of title and he hands the good over, this means that the latter will become the possessor for the owner. If this possessor then sells and delivers the good constituto possessorio to a third party, the third party cannot

44 'Ondanks onbevoegdheid van de vervreemder is een overdracht overeenkomstig artikel 90, 91 of 93 van een roerende zaak, niet-registergoed, of een recht aan toonder of order geldig, indien de overdracht anders dan om niet geschiedt en de verkrijger te goeder trouw is.'

45 Rutgers 1999, p. 24.

46 Ibid.

47 'Een verkrijger die binnen drie jaren na zijn verkrijging gevraagd wordt wie het goed aan hem vervreemdde, dient onverwijld de gegevens te verschaffen, die nodig zijn om deze terug te vinden of die hij ten tijde van zijn verkrijging daartoe voldoende mocht achten. Indien hij niet aan deze verplichting voldoet, kan hij de bescherming die de artikelen $86,86 \mathrm{a}$ en $86 \mathrm{~b}$ aan een verkrijger te goeder trouw bieden, niet inroepen.' 
invoke the protection from article 3:86 paragraph $1 \mathrm{BW}$. This is because art. 3:111 BW states that someone who holds a good for someone else cannot deliver constituto possessorio, because in order to deliver constituto possessorio you need to have the possession of the good..$^{8}$ In this case the delivery requirement would lack and article 3:86 paragraph does not protect this.

\subsubsection{Germany}

In Germany, a third party that bought a good in good faith from someone that was not entitled to sell the good, is protected by $\S 932 \mathrm{BGB}$. If the third party wants to invoke the protection of this article he must meet two requirements. ${ }^{49}$ First, he must have been in good faith at the moment he acquired the good. Second, he must have obtained possession of the good. The good faith means that the third party must have thought that the transferor was the owner of the good at the moment of acquisition. ${ }^{50}$ Paragraph 2 of this article mentions two situations in which the third party is not considered having good faith. ${ }^{51}$ The first situation concerns the case, in which the third party is aware of the fact that the seller does not have the legal ownership of the good. The second situation concerns the case, in which the third party is not aware of this fact as a result of gross negligence. The party has the duty to inquire whether the goods are encumbered with a reservation of title clause, because nowadays goods are usually sold under a reservation of title clause. The third party usually is considered to be grossly negligent if he omits this inquiry. ${ }^{22}$ If the seller is a merchant who sells his good in the course of his business, specific rules mentioned in $\S 366 \mathrm{HGB}$ apply for the good faith requirement. In this situation the third party does not have to think that the seller is the owner of the good, he only has to

48 'Wanneer men heeft aangevangen krachtens een rechtsverhouding voor een ander te houden, gaat men daarmede onder dezelfde titel voort, zolang niet blijkt dat hierin verandering is gebracht, hetzij ten gevolge van een handeling van hem voor wie men houdt, hetzij ten gevolge van een tegenspraak van diens recht.'

'Durch eine nach $\$ 929$ erfolgte Veräußerung wird der Erwerber auch dann Eigentümer, wenn die Sache nicht dem Veräußerer gehört, es sei denn, dass er zu der Zeit, zu der er nach diesen Vorschriften das Eigentum erwerben würde, nicht in gutem Glauben ist. In dem Falle des $§ 929$ Satz 2 gilt dies jedoch nur dann, wenn der Erwerber den Besitz von dem Veräußerer erlangt hatte.' Rutgers 1999, p.

51 'Der Erwerber ist nicht in gutem Glauben, wenn ihm bekannt oder infolge grober Fahrlässigkeit unbekannt ist, dass die Sache nicht dem Veräußerer gehört.' 
believe that the seller has the right to dispose the ownership of the good. ${ }^{53} \mathrm{I}$ believe that this specific rule applies to trade because nowadays it is normal that someone already resells a good, despite of the fact that he did not yet became the owner because of a retention of title clause. If this specific rule would not exist, trade would be disturbed, because a buyer that wants to resell a good then first has to wait until he becomes the owner of the good. And if he resells the good, this means that the seller receives money with which he can pay the claim from his seller. The second requirement stated in $\S 932$ $\mathrm{BGB}$, is that the third party must have obtained the possession of the good. German law does not require that the third party obtained the good for value. $§ 932$ BGB covers as well the purchase for value as the gratuitous purchase..$^{54}$ If the third party acquired the good on constructive delivery, he will not be able to get protection from $\S 932$ BGB.55 If the transferor hands over the good to him after a constructive delivery he will be protected, unless he is not in good faith at that time, according to $\$ 933$ BGB. ${ }^{56}$

\subsubsection{France}

In France the third party that buys a good from someone that not has the ownership of the good can successfully invoke protection by art. 2279 CC, if he meets certain requirements. ${ }^{57}$ The first requirement that has to be met is that the third party must have the actual control over the good and he must have the intention to become the owner of the good. The second requirement that has to be met is that the third party must possess the good in good faith, this requirement is stated in art. 1141 CC, which is a species of the general rule of art. $2279 \mathrm{CC} . .^{58}$ The third party will meet this requirement if he believed without any doubt that the person with whom he concluded the contract was the owner of the good. ${ }^{59}$ French law does not require that the good was obtained for value, if he obtained the good gratuitously he will as well be protected by art. 2279 CC. ${ }^{60}$

\footnotetext{
53 Rutgers 1999, p. 42.

54 Rutgers 1999, $p$.

55 Van Vliet 2011, p.

56 'Gehört eine nach $§ 930$ veräußerte Sache nicht dem Veräußerer, so wird der Erwerber Eigentümer, wenn ihm die Sache von dem Veräußerer übergeben wird, es sei denn, dass er zu dieser Zeit nicht in gutem Glauben ist.'

57 'En fait de meubles, la possession vaut titre.'

58 Rutgers 1999, p. 59.

59 Rutgers 1999, p. 60.

60 lbid.
} 
If the good was delivered to the third party by traditio constituto possessorio, he will not be protected. ${ }^{61}$

\subsubsection{England}

In England the bona fide purchaser is protected by art. 25 SGA if he meets two requirements. ${ }^{62}$ The third party must have good faith at the moment of delivery and he must have obtained the good for value. If he obtains the good gratuitously, he cannot invoke the protection of art. 25 SGA. The good can be delivered by actually handing over the good or by traditio consituto possessorio, this was determined in Gamer's Motor Centre Pty Ltd $v$ Natwest Wholesale [1987]. ${ }^{63}$ The judges in this case held that delivery in art. 25 SGA covers actual delivery as well as constructive delivery. ${ }^{64}$ So in England the bona fide purchaser is also protected if the possession over the good is delivered to him by traditio consituto possessorio, unless he is not in good faith and did not obtain the good for value of course.

\section{Extinction: Specification and Accessio}

The main reason why a retention of title will extinct is because the buyer fulfilled the condition which usually is the payment of the purchase price. This section deals with two other ways whereupon a retention of title can extinct. These are specificatio and accessio. I will look at the rules for this in the four Member States and what the consequence is for a retention of title clause, and therefore for the ownership of the seller. Specificatio and accessio are two forms of original acquisition of ownership. This means that new ownership comes in existence.

\subsection{Specificatio}

Specificatio means that someone uses materials in order to produce a new thing. If the materials are produced and the result is a new thing, the materials lose their legal independence and consequently the ownership in the materials is lost. ${ }^{65}$ The new

\footnotetext{
61 Van Vliet 2011, p.

62 Van Vliet 2011, p.

63 Van Vliet 2011, p.

64 Van Vliet 2011, $p$.

65 Wichers 2002, p. 173.
} 
produced thing has legal independence and therefore someone can own the thing. ${ }^{66}$ If the person that used the materials was the owner of these materials, no problems will arise, because he will then become the owner of the new produced thing. But if the producer bought the goods from a seller and the seller made a retention of title clause, the producer does not yet own the materials. If this is the situation and the materials did not, or not all [if he also used materials belonging to himself], belong to the producer, a problem arises, because who will then become the owner of the new produced thing? The rules for specificatio in the four Member States will be discussed here below.

\subsubsection{The Netherlands}

Specificatio is stated in art. 5:16 BW. Paragraph 1 states that art. 5:14 BW, about accessio, applies if someone produces a new thing for someone else from one or more moveable objects, which belonged to different owners. ${ }^{67}$ Accessio means that two things are attached to each other. ${ }^{68}$ If the producer produced for himself then he will become the owner of the new thing, unless the costs of the production are so low that they do not justify this result, according to art. 5:16 paragraph 2 BW. ${ }^{69}$ Art. 5:14 paragraph 1 BW states that if a moveable thing becomes a component of another moveable thing, the owner of the principal thing becomes the owner of the attached thing. ${ }^{70}$ Paragraph 2 states that if none of the things can be considered as the principal thing, and they belonged to different owners, these owners become co-owners of the new thing. ${ }^{71}$ Paragraph 3 states which thing has to be considered as the main thing. The principal thing is the thing from which the value exceeds the value of the other thing or the thing which according to the common opinion is considered as the main thing..$^{72}$ For instance a motor that is placed in a car, which has a

66 Wichers 2002, p. 174.

67 'Indien iemand uit een of meer roerende zaken een nieuwe zaak vormt, wordt deze eigendom van de eigenaar van de oorspronkelijke zaken. Behoorden deze toe aan verschillende eigenaars, dan zijn de vorige twee artikelen van overeenkomstige toepassing.'

68 Wichers 2002, p. 119.

69 'Indien iemand voor zichzelf een zaak vormt of doet vormen uit of mede uit een of meer hem niet toebehorende roerende zaken, wordt hij eigenaar van de nieuwe zaak, tenzij de kosten van de vorming dit wegens hun geringe omvang niet rechtvaardigen.'

70 'De eigendom van een roerende zaak die een bestanddeel wordt van een andere roerende zaak die als hoofdzaak is aan te merken, gaat over aan de eigenaar van deze hoofdzaak.'

71 'Indien geen der zaken als hoofdzaak is aan te merken en zij toebehoren aan verschillende eigenaars, worden deze mede-eigenaars van de nieuwe zaak, ieder voor een aandeel evenredig aan de waarde van de zaak.'

72 'Als hoofdzaak is aan te merken de zaak waarvan de waarde die van de andere zaak aanmerkelijk overtreft of die volgens verkeersopvatting als zodanig wordt beschouwd.' 
value that exceeds the value of the car will not be considered as the principal thing, this will be the car, because this is the common opinion. The division between specificatio and accessio lies in the question whether a new thing came in existence. ${ }^{73}$ This question is answered by the common opinion. A new thing came in existence if the original thing or things do not anymore exist as such, and if the new thing is essentially different from the original thing or things..$^{74}$ This article is ius cogens and parties cannot agree otherwise..$^{75}$

\subsubsection{Germany}

Specificatio is dealt with in $\S 950$ BGB. The general rule is that the person that produces the new thing acquires the ownership of the new thing. ${ }^{6}$ This rule however does not apply if the value of the production is substantially less than the value of the substance. This rule is ius cogens, but in Germany the parties can agree by contract that the buyer produces for the seller and that the seller therefore becomes the owner of the new thing, because he is considered to be the producer. ${ }^{77}$ This is called a Verarbeitungs -oder Herstellerklausel. ${ }^{78}$ German courts use a combination between the objective and the subjective standard to determine who the owner is. ${ }^{9}$ It is determined by the perspective of an insider that is aware of the terms between the seller and the buyer. So if parties agree that the buyer produces for the seller, the seller is regarded to be the owner. However, if the factual situation does not comply with the terms in the contract, the buyer becomes the owner. ${ }^{80}$ Parties can also agree that the seller and the buyer become co-owners of the new produced thing. ${ }^{81}$

\subsubsection{France}

Art. 565 CC states that if things, belonging to different owners, are combined, the outcome of the case depends on principles of natural equity. The Civil Code however

\footnotetext{
73 Wichers 2002, p. 190.

74 Wichers 2002, p. 191.

75 Van Vliet 2011, p.

76 'Wer durch Verarbeitung oder Umbildung eines oder mehrerer Stoffe eine neue bewegliche Sache herstellt, erwirbt das Eigentum an der neuen Sache, sofern nicht der Wert der Verarbeitung oder der Umbildung erheblich geringer ist als der Wert des Stoffes. Als Verarbeitung gilt auch das Schreiben, Zeichnen, Malen, Drucken, Gravieren oder eine ähnliche Bearbeitung der Oberfläche.'

77 Van Vliet 2011, p.

78 Rutgers 1999, p. 47.

79 Van Vliet 2011, p.

80 Van Vliet 2011

$81 \quad$ Van Vliet 2011
} 
mentions a few rules that can serve the judge in order to decide on the outcome of a case..$^{82}$ If the case is about specificatio art. 571 CC is used. This article states that the producer of the new thing becomes the owner of the new thing, unless the cost of his work does not exceed the value of the materials used. ${ }^{83}$ This rule is ius dispositivum and parties therefore can agree otherwise. ${ }^{84}$ The seller and the buyer can agree that the retention of title of the seller is extended to the product made from the materials delivered to the buyer. ${ }^{85}$ This extension also has effect against third parties. ${ }^{86}$

\subsubsection{England}

The rules on specificatio in England have to be derived from case law, since there is no legislation on this subject. A case that deals with production is Borden (UK) Ltd v. Scottish Timber Products Ltd [1981]. ${ }^{87}$ If materials, from different owners, are used in the production of a new thing, the producer of the new thing becomes the owner of the new thing, unless the costs of the production do not justify this result. Parties cannot agree otherwise. ${ }^{88}$ The retention of title clause will then not be uphold and the seller will therefore lose his ownership of the good. ${ }^{89}$

\subsection{Accessio}

Accessio means that two moveable things are attached in such a way that one of the two movable things becomes a component of the other moveable thing, the principle thing. ${ }^{\circ}$ The thing that becomes the component of the other thing loses its legal independence

82 'Le droit d'accession, quand il a pour objet deux choses mobilières appartenant à deux maîtres différents, est entièrement subordonné aux principes de l'équité naturelle. Les règles suivantes serviront d'exemple au juge pour se déterminer, dans les cas non prévus, suivant les circonstances particulières.'

83 'Si, cependant, la main-d'oeuvre était tellement importante qu'elle surpassât de beaucoup la valeur de la matière employée, l'industrie serait alors réputée la partie principale, et l'ouvrier aurait le droit de retenir la chose travaillée, en remboursant au propriétaire le prix de la matière, estimée à la date du remboursement.'

84 Van Vliet 2011.

85 Van Vliet 2011.

86 Van Vliet 2011.

87 Feld 1992, p. 2.

88 Van Vliet 2011.

89 Feld 1992, p. 2.

90 Wichers 2002, p. 119. 
and therefore the person that owned this thing loses its ownership. The owner of the principal thing becomes the owner of the new component as well. An example of accessio is the situation in which a bicycle bell is attached to a bicycle. The bicycle is the principal thing and therefore the bicycle bell becomes a component of the bicycle. The bicycle bell loses his legal independence and the owner of the bicycle also acquires the ownership in the bicycle bell. Well, if the owner of the bicycle bell was the same as the owner of the bicycle, no problems will arise. But, if the bicycle bell and the bicycle were owned by different owners, a problem arises. The rules for accessio of moveable things in the different Member States will be discussed here below.

\subsubsection{The Netherlands}

Accessio is stated in art. 5:14 BW. Paragraph 1 states that the ownership of a moveable thing, which becomes a component of another moveable thing that is considered to be the principal thing, passes to the owner of this principal thing..$^{91}$ In order to answer the question whether someone became a component of another thing, we first have to look at art. 3:4 BW.92 Paragraph 1 of this article states that everything that according to the common opinion is considered a part of a thing, is a component of that thing. ${ }^{93}$ Paragraph 2 states that if a thing is attached to a principal thing in such a way that detachment cannot take place without damaging one of the things, that thing becomes a component of the principal thing. ${ }^{94}$ If the answer to the question whether something became a component of another thing is answered with yes, we have to look art. 5:14 BW again. Paragraph 3 states which thing has to be considered as the principal thing. The principal thing is the thing from which the value significant exceeds the value of the other thing or the thing that according to the common opinion is considered to be the principal thing. ${ }^{95}$ Paragraph 3 states that if none of the things, that belong to different owners, can be considered to be the principal thing, the owners become co-owners, each for a share that is proportional to the value of the thing they own. ${ }^{6}$

91 'De eigendom van een roerende zaak die een bestanddeel wordt van een andere roerende zaak die als hoofdzaak is aan te merken, gaat over aan de eigenaar van deze hoofdzaak.'

92 Wichers 2002, p. 119.

93 'Al hetgeen volgens verkeersopvatting onderdeel van een zaak uitmaakt, is bestanddeel van die zaak.'

94 'Een zaak die met een hoofdzaak zodanig verbonden wordt dat zij daarvan niet kan worden afgescheiden zonder dat beschadiging van betekenis wordt toegebracht aan een der zaken, wordt bestanddeel van de hoofdzaak.'

95 'Als hoofdzaak is aan te merken de zaak waarvan de waarde die van de andere zaak aanmerkelijk overtreft of die volgens verkeersopvatting als zodanig wordt beschouwd.'

96 'Indien geen der zaken als hoofdzaak is aan te merken en zij toebehoren aan verschillende eigenaars, worden deze mede-eigenaars van de nieuwe zaak, ieder voor een aandeel evenredig aan de waarde van de zaak.' 


\subsubsection{Germany}

Accessio is stated in $\S 947$ BGB. Paragraph 1 of this article states that if moveable things, with different owners, are combined with each other in such a way that they become essential parts of a uniform thing, the previous owners become co-owners of the new thing. ${ }^{97}$ They each get a share in the new thing that is determined by the relationship of the value that the things have at the time of the combination. This is also states in $\S 93$ BGB. This article states that things that are attached in such a way that they cannot be separated without damaging one of the things, cannot be a subject of separate rights..$^{98}$ This is the reason why the owners then become co-owners. Paragraph 2 of $\$ 947$ BGB states that if one of the things is considered to be the principal thing, its owner acquires soleo wnership. 99

\subsubsection{France}

Art. $565 \mathrm{CC}$ states that if things, belonging to different owners, are combined, the outcome of the case depends on principles of natural equity. ${ }^{100}$ The Civil Code however mentions a few rules that can serve the judge in order to decide on the outcome of a case. If the case is about accessio art. 566 till 569 CC apply. Art. 566 CC states that if two moveable things are combined in such a way that they cannot be separated the owner of the principal thing becomes the owner of other thing, and that this owner then has the obligation to pay the other owner the value of his lost thing. ${ }^{101}$ Art. 567 and 569 CC give an answer to the question what has to be considered as the principal thing. Art. ${ }_{567} \mathrm{CC}$ states that the thing to which the other has been joined only for the use, ornamentation or completion

97 'Werden bewegliche Sachen miteinander dergestalt verbunden, dass sie wesentliche Bestandteile einer einheitlichen Sache werden, so werden die bisherigen Eigentümer Miteigentümer dieser Sache; die Anteile bestimmen sich nach dem Verhältnis des Wertes, den die Sachen zur Zeit der Verbindung haben.'

98 Bestandteile einer Sache, die voneinander nicht getrennt werden können, ohne dass der eine oder der andere zerstört oder in seinem Wesen verändert wird (wesentliche Bestandteile), können nicht Gegenstand besonderer Rechte sein."

99 Ist eine der Sachen als die Hauptsache anzusehen, so erwirbt ihr Eigentümer das Alleineigentum.'

100 'Le droit d'accession, quand il a pour objet deux choses mobilières appartenant à deux maîtres différents, est entièrement subordonné aux principes de l'équité naturelle. Les règles suivantes serviront d'exemple au juge pour se déterminer, dans les cas non prévus, suivant les circonstances particulières.'

101 'Lorsque deux choses appartenant à différents maîtres, qui ont été unies de manière à former un tout, sont néanmoins séparables, en sorte que l'une puisse subsister sans l'autre, le tout appartient au maître de la chose qui forme la partie principale, à la charge de payer à l'autre la valeur, estimée à la date du paiement, de la chose qui a été unie.' 
of the first thing has to be considered as the principal thing. ${ }^{102}$ Art. ${ }^{6} 69 \mathrm{CC}$ states that the principal thing is the thing which has the greater value, or the greater volume in case the values are approximately equal. ${ }^{103}$ Art. 568 CC states that if the owner of the thing that is combined with the other thing, did not know that his thing was combined with another thing can request the return of his thing by separating it from the other thing, even though this may damage the other thing. ${ }^{104}$ Art. 2370 CC states that if a thing, whose title is retained, is incorporated to another thing does not affect the retention of title of the seller if the things can be separated without causing damage to one of the two things. ${ }^{105}$

\subsubsection{England}

The rules on accessio in England have to be derived from case law, since there is no legislation on this topic. The general rule when two moveable things are combined in such a way that they cannot be separated is that the owner of the principal thing becomes the owner of the other thing. ${ }^{106}$ The principal thing is the thing which value exceeds the value of the other thing. ${ }^{107}$ In the situation in which two moveable things, with different owners, are combined in such a way that they can readily be identified and separated, accessio will not take place. ${ }^{108}$ The things do not lose their legal independence and the owners therefore do not lose their ownership. ${ }^{109}$ So in the case in which a buyer combines a moveable thing belonging to him and a moveable thing belong to his seller, because of a retention of title clause, and the things can be easily identified and separated, the retention of title clause will be upheld and the seller will not lose his ownership. This was determined in the Hendy Lennox Ltd $v$ Graham Puttick Ltd case [1984]. ${ }^{110}$

102 'Est réputée partie principale celle à laquelle l'autre n'a été unie que pour l'usage, l'ornement ou le complément de la première.'

103 'Si de deux choses unies pour former un seul tout, l'une ne peut point être regardée comme l'accessoire de l'autre, celle-là est réputée principale qui est la plus considérable en valeur, ou en volume, si les valeurs sont à peu près égales.'

104 Néanmoins, quand la chose unie est beaucoup plus précieuse que la chose principale, et quand elle a été employée à l'insu du propriétaire, celui-ci peut demander que la chose unie soit séparée pour lui être rendue, même quand il pourrait en résulter quelque dégradation de la chose à laquelle elle a été jointe.'

105 L'incorporation d'un meuble faisant l'objet d'une réserve de propriété à un autre bien ne fait pas obstacle aux droits du créancier lorsque ces biens peuvent être séparés sans subir de dommage.'

106 Knobel 2011, p. 301.

107 Knobel 2011, p. 302

108 Knobel 2011, p. 301.

109 Feld 1992, p. 1.

110 lbid. 


\section{Cases}

In this section three different cases will be dealt with. I will answer every case according to the rules that exist in the four Member States. After this I will compare the answers and conclude what the differences and the similarities are.

\subsection{Case 1: Bona Fide Purchaser}

A sells and delivers a piano under a retention of title to $B$. B resells and delivers the piano to $C$ by real possession, despite the fact that $B$ still has not paid the purchase price and therefore has not become the owner. $C$ is not aware of the contract and the retention of title clause between A en B.

Q1. What happens with the retention of title from A?

Let's say that B did not deliver the piano by real possession but constituto possessorio.

Q2. Does it matter that B delivered the piano constituto possessorio?

\subsubsection{The Netherlands}

Q1. In the Netherlands the retention of title of $A$ would end if $C$ had good faith at the moment of acquisition and if $\mathrm{C}$ had to perform a duty in order to acquire the piano. So, $\mathrm{C}$ must have paid a purchase price for the piano. $\mathrm{C}$ did not know about the retention of title clause between $A$ and $B$ and can therefore meet the good faith requirement. $C$ also paid a purchase price for the piano and can therefore also meet the second requirement. The retention of title from $\mathrm{A}$ will end, therefore he will lose his ownership and C will become the new owner of the piano.

Q2. Yes this matters. C will not be protected against the fact that B did not have the right to dispose the ownership of the good, as long as $B$ possesses the piano for $C$. If $C$ would really deliver the goods to $\mathrm{C}$ - and the other requirements are met - A will lose his ownership and $\mathrm{C}$ will become owner.

\subsubsection{Germany}

Q1. In Germany C will be protected against the fact that B did not have the right to dispose the ownership of the piano if he had good faith at the moment of acquisition. $C$ was not aware of the retention of title clause and $C$ therefore will become the new owner and $A$ will lose his ownership. 
Q2. Yes this would matter. C will only be protected if he obtained the real possession of the piano. He will not be protected if the delivery was consituto possessorio.

\subsubsection{France}

Q1. In France $C$ will get protection if he had good faith at the moment of acquisition. This is the case and therefore $\mathrm{C}$ will become the new owner.

Q2. Yes, this would matter. C will not get protection if the piano was delivered to him constituto possessorio.

\subsubsection{England}

Q1. In England C will be protected if he had good faith at the moment of delivery and if he paid for the piano. In this case $\mathrm{C}$ did not know about the retention of title clause between $A$ and B. C also paid a purchase price for the piano and therefore $C$ will become the owner.

Q2. No, this would not matter. In England C will also be protected if B delivered the piano constituto possessorio.

\subsubsection{Comparison}

As regard to the requirements in order for a third party to be protected against the fact that the reseller did not have the right to dispose the ownership of the good, the following can be said. Every Member State requires that the third party had good faith. The Netherlands and England have an additional requirement that the third party must have paid a purchase price for the good. As regard the method of delivery only England allows constituto possessorio if the third party want to rely on protection. In the other Member States the third party will not be protected as long as the delivery is constituto possessorio.

So, the question whether A's retention of title clause will end and he therefore will lose his ownership, depends on the fact which law will be applied to the retention of title clause. In a case in which B would have delivered constituto possessorio this would lead to big differences in the outcome of a case.

\subsection{Case 2: Specificatio}

A sells and delivers materials for the production of clothing under a retention of title to $B$. $B$ uses the materials in the production and the result of the production is new clothing. $B$ produces for himself. 
Q1. What happens with the retention of title from $A$ and who becomes the owner of the new clothing?

Q2. Can parties agree otherwise?

\subsubsection{The Netherlands}

Q1. B produces for himself and he uses the materials delivered to him by A under a retention of title. B will become the owner, unless the costs of the production do not justify this. This case says nothing about this possibility and therefore $B$ becomes the owner of the new clothing.

Q2. Parties cannot agree otherwise.

\subsubsection{Germany}

Q1. B produces for himself and he uses the materials delivered to him by A under a retention of title. B will become the owner, unless the costs of the production do not justify this. This case says nothing about this possibility and therefore B becomes the owner of the new clothing.

Q2. Yes, parties can agree otherwise. They can agree that the buyer produces for the seller. The seller then has to be considered the produces and therefore he will become the owner of the new clothing.

\subsubsection{France}

Q1. B produces for himself and he uses the materials delivered to him by A under a retention of title. B will become the owner, unless the costs of the production do not justify this. This case says nothing about this possibility and therefore B becomes the owner of the new clothing.

Q2. Yes, parties can agree otherwise. They can agree that the buyer produces for the seller. The seller then has to be considered the produces and therefore he will become the owner of the new clothing.

\subsubsection{England}

Q1. B produces for himself and he uses the materials delivered to him by A under a retention of title. B will become the owner, unless the costs of the production do not justify this. This 
case says nothing about this possibility and therefore B becomes the owner of the new clothing.

Q2. Parties cannot agree otherwise.

\subsubsection{Comparison}

It can be said that the seller receives more protection in Germany and France than in the Netherlands and England. In Germany and France the seller and the buyer can agree that the seller has to be considered as the producer and therefore he will become the owner of the new produced thing.

\subsection{Case 3: Accessio}

A sells and delivers a steering wheel for a car under a retention of title to B. B needs a new steering wheel because his old steering wheel broke off and could not anymore be attached to the car. B firmly attaches the new steering wheel from A to his car, which value exceeds the value of the steering wheel.

Q1. What happens with the retention of title from $A$ and who becomes the owner of the steering wheel?

\subsubsection{The Netherlands}

Q1. The steering wheel is considered to be a component from the car according to the common opinion. Furthermore, the steering wheel cannot be detached without causing damage to the steering wheel and/or the car. Furthermore, the value of the car exceeds the value of the steering wheel. Therefore the car has to be considered as the principal thing. In the Netherlands the owner of the principal thing as well becomes the owner of a new attached component. So the retention of title from A would extinct and B would become the owner of the steering wheel.

\subsubsection{Germany}

Q1. In Germany if two moveable things are combined, the owner of the principal thing becomes the owner of the other thing. The car has to be considered as the principal thing. Therefore A's retention of title would extinct and B would become the owner of the steering wheel. 


\subsubsection{France}

Q1. In France if two moveable things, with different owners are combined, the outcome of the question who becomes the owner depends on principles of natural equity. However there are a few rules that can help the judge with answering this question. If two moveable things are combined in such a way that they cannot be detached without damaging one of the two things, the owner of the principal thing becomes the owner of the other thing. The principal thing is the thing which value exceeds the value of the other thing or the thing to which the other has been attached only for the use, ornamentation or completion of the first thing. The car's value exceeds the value of the steering wheel, furthermore the steering wheels is only attached for the use and completion of the car. A car without a steering wheel is useless. Therefore, A's retention of title would extinct and B would become the owner of the steering wheel.

\subsubsection{England}

Q1. In England if the two moveable things are combined in such a way that they cannot readily be identified and separated, the owner of the principal thing becomes the owner of the other thing. The principal thing is the thing which value exceeds the value of the other thing. The car's value exceeds the value of the steering wheel. Therefore, A's retention of title will extinct and B will become the owner of the steering wheel.

\subsubsection{Comparison}

The outcome of the case would be the same in the four Member States. In each case the owner of the principal thing becomes the owner of the other thing. In all the four Member States the principal thing is the thing which value exceeds the value of the other thing. However, the Netherlands also has the criteria of what is considered to be the principal thing according to the common opinion. And in France they also use the criteria whether a thing only is attached for the use, ornamentation or completion of the other thing. So, in the case in which a motor with a value of 10.000 Euros would be placed in a car with a value of 2000 Euros, differences in the outcome could arise. If a Member States only looks at the value of the things then the motor will be considered as the principal thing. If a Member State also looks at the common opinion or at for which reason two moveable things were combined, then the car will be considered as the principal thing. So, the general rule in each Member States for who becomes the owner does not differ. However, the rules for what has to be considered as the principal thing differs and this could lead to different outcomes, depending on which moveable things are combined. 


\section{Is harmonization needed?}

What would harmonization of retention of title mean? Harmonization of retention of title would mean that every seller gets the same degree of protection in the European Union, and that the simple fact that the legal regime from Member State A will be applied, and not the legal regime from Member State B, will not lead to big differences in the outcome. Furthermore harmonization of retention of title will give parties, and other persons concerned, more certainty about which rules will be applied and what the outcome of a case therefore could be. The three cases have shown that the outcome of a case depends on which law will have to be applied and that there are big differences.

But before answering the question whether harmonization is necessary, I will first show whether there already is some sort of harmonization on this field. There is no harmonization that only concerns retention of title. The only thing that I could find which mentions retention of title is Directive 2000/35 EG on combating late payments in commercial transactions." ${ }^{11}$ In art. 4 of this Directive is stated that the Member States have to look after the fact that the seller retains the ownership in a good, until payment is fully made, if the seller and the buyer agreed on a retention of title clause. ${ }^{12}$ The Court of Justice was asked to explain this article in the Commission $v$ Italy case. ${ }^{13}$ This case was about the fact that Italian legislation obliged the seller to mention the agreed on retention of title on every document that confirms the performance of the original agreed on contract. If the seller would fail to do so, the retention of title clause would not have effect against third parties. The Court of Justice had to determine whether this Italian rule was in conflict with art. 4 of the Directive. The Court held that art. 4 of the Directive only stated that if the seller and the buyer agreed on a retention of title clause, the seller would retain the ownership until payment is fully made. The Court determined that art. 4 did not affect the validity of other national rules. Therefore the Italian rule was not in conflict with art. 4 of the Directive. This means that a seller when concluding a contract with a buyer in a different Member State still has to research all the national rules in that Member State in order to know which formalities for retention of title exist in that Member State in order to be effective against third parties. This costs a lot of money and time and furthermore,

111 Directive 2000/35/EC.

112 'Member States shall provide in conformity with the applicable national provisions designated by private international law that the seller retains title to goods until they are fully paid for if a retention of title clause has been expressly agreed between the buyer and the seller before the delivery of the goods.'

Court of Justice EU, 26 October 2006, C-302/5 (Commission/Italy). 
when does a seller know that he found all the rules and did not miss an important rule?

The differences in the rules mean that the protection that is granted to a seller simply depends on which law is applicable. The law that is applicable to a retention of title clause depends on in which country the good is located, this is known as the lex rei sitae. ${ }^{114}$ The fact that some Member States grant more protection to a seller could lead to situations in which the person that has the factual control over the good can simply change the applicable law by bringing the good into another Member State. Furthermore, the fact that Member State can have their own rules for the formation of a retention of title clause means that sellers must examine the rules existing in a Member State in which a buyer lives with whom he is going to conclude a contract.

When I look at the different outcomes of the cases mentioned in section 6 and the fact that Member States can have their own rules for the formation of a retention of title, I can only conclude that harmonization is needed. Because of the fact that the European Union becomes each year more a unity and of the fact that the amount of cross-border sale of good contracts increases every year, it is important to have the same kind of rules that are applicable to cross-border sale of good contracts, in which the seller and the buyer agreed on a retention of title clause. If the same rules would be applied to retention of title, independent of the fact of which law is applicable, this would mean more certainty for everyone. Not only for the seller, that then will know which formalities he has to take into account and that then will know on which ways his retention of title can extinct, but also for the buyer and for third parties. If the same rules would be applied the seller would not have to worry about which law will be applicable.

\section{Legal Systems of the Member States}

In this section the legal systems of the four Member States will be discussed. I think that this is important in order to be able to answer the question whether harmonization is feasible, because harmonization is not possible if the legal regimes of the Member States are constructed in such way that they do not allow harmonization on the field of retention of title. The principle of numerus clausus is a very important principle when it comes to the question whether harmonization of retention of title is feasible. This principle refers

114 Akkermans 2012, p. 2. 
to a closed list of property rights. ${ }^{115}$ This means that parties cannot create their own new property rights. If they create a property right and that right fulfils the criteria set in the law for that type of property right, then it has property-right and therefore it then has effect against third parties. ${ }^{116}$

The Dutch legal system is a mixture of the French and German legal system. ${ }^{17}$ The Dutch legal system, inspired by the German legal system, introduced the principle of numerus clausus in 1905. In this year the Supreme Court of the Netherlands, the Hoge Raad, decided on a case which changed the Dutch Property Law system. ${ }^{18}$ This case meant the distinction between personal and property rights. The numerus clausus principle was codified in 1992."19

The German legal system is a mixture of the Germanic and Roman legal system. ${ }^{20}$ The principle of numerus clausus was introduced in 1900 with the introduction of the BGB. ${ }^{121}$ Since the BGB went into force several new property rights were recognised. ${ }^{122}$ An example of a new property right that was recognised is the Anwartschaftsrecht. ${ }^{123}$ This is the right that the buyer gets if the seller and the buyer agreed on a retention of title clause.

The French Civil Code was introduced in 1804, and was a source of inspiration for both the drafters of the BGB as well as the drafters of the BW. ${ }^{124}$ In France the principle of numerus clausus determines which property rights are recognised and have property-right. However this principle is not as clear and strict as in other civil law systems, because the French legislature and the Cour de cassation, both have shown that they are willing to create or recognise new property rights. ${ }^{25}$

England has a common law system, this means that England, unlike The Netherlands, Germany and France, never adopted a Civil Code. There is one big difference between the English Common law system and the Civil law systems from The Netherlands, Germany and France. If the legislature in the Civil law systems wants to create or recognise a new

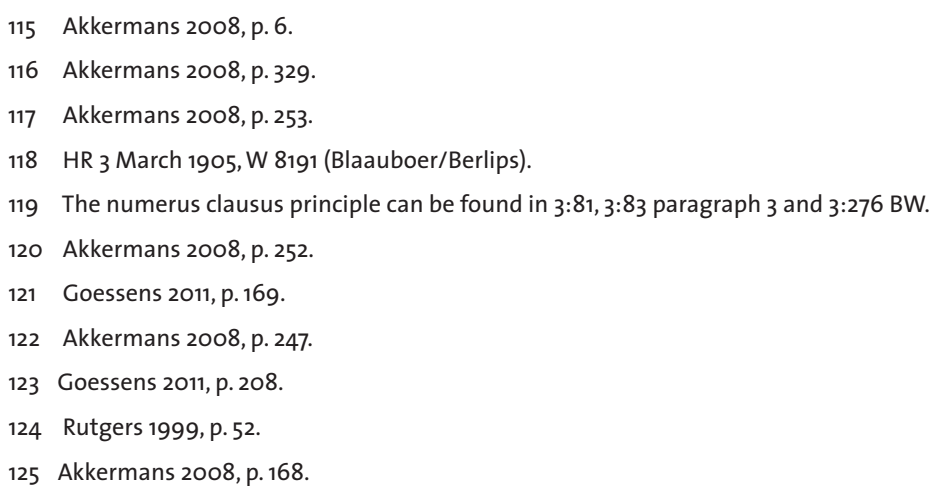


property right, he must alter the Civil Code. In England judges can keep developing Property Law until they are stopped by the legislature. ${ }^{126}$ In England's law system the principle of numerus clausus exists. ${ }^{27}$

\section{Is harmonization feasible?}

Harmonization of the rules for retention of title would mean that in some Member States seller would be granted more protection and in some Member States sellers would be granted less protection than now. In my opinion the debate on the question whether there should be harmonization of the field of Property Law does not regard the various existing rules, but the various existing Property Law systems. As long as Member States will have different Property Law systems real harmonization will not be reached in my opinion, because it can only be reached if the systems would be almost the same and therefore could have the same rules. An example of my reasoning is a case about the possibility that exists in German Property Law to extend the retention of title to the product as a result of combination. A German seller and a Dutch buyer agree on a contract of sales. In this contract they agree on a retention of title clause, in which is stated that if the buyer uses the good in a production, he is considered to produce for the seller, and therefore the seller will then become the owner of the new thing. They also agree that the buyer has to pay the purchase price within a time period of one month. The seller delivers the good and the buyer uses the good in a production. One month expires after the conclusion of the contract and the buyer still has not paid the purchase price. The seller now wants to revindicate the new thing, since he became the owner according to German Property Law. If a Dutch court would determine the outcome of this case and the case would have to be enforced in the Netherlands it would determine that the retention of title has expired because the good lost its judicial identity in the production and the property in the good therefore was lost. The specific clause would not have a property-right and therefore no third parties effect, because the Dutch Property Law system does not know this method of acquiring property and because of the Dutch numerus clausus. If a German court would determine the outcome of the case and the case would have to be enforced in Germany, it would determine that the seller has become the owner of the new thing, because of the

126 Akkermans 2008, p. 387.

127

Akkermans 2008, p. 396. 
retention of title clause, and the seller therefore can claim revindication of the new thing. So, in this case the Dutch Property Law regime would prevent the effect of the retention of title clause. This could only be solved by changing the Dutch Property Law regime, that is to say to make it an open system, or by an alteration of Dutch Property Law rules.

Neither the Netherlands, nor another Member States in which the principle of numerus clausus exist, would set this principle aside and make their system an open system. By doing this Member States would allow foreign property rights to come into their legal system. Furthermore, it would allow parties to create their own property rights. This would mean that third parties cannot know which rights exist on a specific good and this cannot be allowed, because it would lead to a lot of uncertainty and could significant disturb the practice of law. The second option, altering the Property Law rules of the Member States, is feasible. If the European Union could come up with rules for retention of title in crossborder contracts and the Member States would agree on these rules, then the Member States could change their legal systems. The description of the legal systems in section 8 showed that the Member States are willing to create of recognise new property rights in their legal system. If it would be rules that can overcome the differences and lead to more certainty and the same degree of protection, then I would not know why Member States would not make the necessary alterations.

However, it must be noted, that every Member State has its own Property Law mentalités and that every Member State has its own law education. For instance, Dutch law students focus on the applicable rules, while English law students focus on the rules in combination with the case. This means that even if the rules are the same a Dutch judge would probably apply the rules in a different way than a English judge.

Furthermore, I want to note that in my opinion real harmonization of retention of title can only be achieved if retention of title and a lot of other topics, such as the practice of a retention of title clause in the buyer's insolvency and the relationship between a retention of title and a pledge, are harmonized. If only the rules on harmonization of retention of title itself are harmonized, such as the rules for the formation, then it would still be that simple fact that the legal regime from Member State A will be applied, and not the legal regime from Member State B, will lead to big differences in the outcome. In my thesis I dealt with the bona fide purchaser, specificatio and accessio, if these topics would be harmonized in relationship to retention of title then it would already lead to more harmonization. But as said before, in order to achieve real harmonization more topics have to be harmonized. 
So, to sum it up, I think that harmonization is feasible, as long as the Member States agree on it. The degree of harmonization would depend on how many topics are harmonized. But it must be remembered that even if the rules on retention of title will be harmonized, the different Property Law mentalités, the different cultures and the differences in education will still lead to a different application from the same rules.

J.M. Smits also states this in his article about European Private Law as a mixed legal system. Smits says that the goals of harmonization are decided on the EU level, but that the achievement of these goals is left to the Member States. ${ }^{128}$ Furthermore Smits states that the methods that have been used in order to achieve harmonization show the thought that the European Union could achieve harmonization, certainty and predictability, simply by introducing uniform rules. ${ }^{22}$ Smits also discusses the arguments of Legrand in his article. Legrand believes that the mere drafting of rules will not lead to unification. ${ }^{130}$

However, Legrand is not against harmonization, but only against harmonization done from above. ${ }^{1{ }^{11}}$ In his article Smits gives an alternative for harmonization. He states that there should be a free movement of legal rules. ${ }^{132}$ This would mean that judges, lawyers and other people practising the law, can choose what the best rule for a specific situation is. According to Smits European Private Law should be created there where it has to be applied, in practice. ${ }^{133}$ I first supported the ideas of Legrand about harmonization of European Private Law. I also agreed that the mere drafting of unifying rules will not lead to unification. However, Legrand does not give an alternative for harmonization done from above. Smits, on the other hand, does give an alternative. The alternative is to create the law in practise, since this also is the place where it has to be applied. If unifying rules are created in this way, I strongly believe that harmonization is feasible.

\footnotetext{
128 Smits 1998, p. 2.

129 Smits 1998, p. 3.

130 Smits 1998, p. 4 .

131 lbid.

132 Smits 1998, p.7.

133 Smits 1998, p. 8.
} 


\section{Conclusion}

The purpose of my research was to figure out whether harmonization of retention of title is needed and if so, if harmonization is feasible. The outcome of the cases used in this thesis in order to answer the harmonization question showed that harmonisation is needed. Under the current law regimes of the Member States of the European Union sellers with a retention of title clause get different degrees of protection. The degree of protection is simply determined by which law is applicable to the retention of title clause. In my opinion this should not be allowed.

\section{Is harmonization needed?}

I know that the results of my research do not give a complete view of retention of title. I used a very small territorial scope, I only looked at four Member States. A complete view can only be achieved if the rules on retention of title from every Member State are described and compared. Furthermore I used a small material scope, I only looked at a bona fide purchaser, specificatio and accessio. There are many more topics that have to be researched in order to really be able to conclude whether harmonization of title is needed, such as for example the relationship between retention of title and limited property rights. And unfortunately this is not something that can be done in a bachelor thesis. Despite of the fact that my thesis does not give a complete view, I nevertheless hope that my thesis shows that there are big differences and that harmonization on this field is necessary.

\section{Is harmonization feasible?}

For my second main question I wanted to research whether harmonization is feasible. I first looked at the legal systems of the four Member States, in order to determine whether they would accept harmonization. After that I researched what harmonization would mean and what is necessary in order to achieve harmonization. I believe that if unifying rules are created on the level of the European Union, that this would not lead to harmonization. Even if every Member State would apply the same rules, they would still apply it in a different way because of their legal culture. I discussed the arguments of Legrand and Smits and I support the ideas of Smits. Legrand and Smits both think that harmonization cannot be achieved from above, because this would still lead to different applications. Smits gives the alternative to create unifying rules in practise, because this is where the rules also have to be applied. If the rules are created in practise, then I truly believe that this could lead to harmonization. 


\section{Bibilography}

\section{Secondary Sources:}

\section{Akkermans 2008}

- B. Akkermans, The Principle of Numerus Clausus in European Property Law (Intersentia, Antwerp-Oxford - Portland, 2008).

\section{Akkermans 2012}

- B. Akkermans \& E. Ramaekers, 'Lex Rei Sitae in Perspective: National Developments of a Common Rule?', Maastricht European Private Law Institute Working Paper No. 2012/14 .

Feld 1992

- J. Feld, 'Retention of title: seller v receiver', The Law Society Gazette (1992).

Goessens 2011

- E. Goessens, 'De historische oorsprong van het numerus clausus beginsel in het goederenrecht', Jura Falconis, jaargang 47, $\mathrm{nr} 1$.

Haentjes 2011

- M. Haentjes, 'DCFR en goederenrecht in de praktijk - over zekerheid en tafelranden', Nederlands Tijdschrift voor Burgerlijk Recht, 2011/54.

Knobel 2011

- Ina Knobel, 'Accession of moveables to moveables and ineadificatio- South Africa and Some Common Law Countries' Journal of Contemporary Roman-Dutch Law, vol. 74, 2011.

\section{Omar 1996}

- P.J. Omar, 'Retention of title clauses in French law', The International Insolvency Institute Academic Forum Collection, (1996).

\section{Reehuis 2010}

- W.H.M. Reehuis, Monografieën BW: Overdracht (4 $4^{\text {th }}$ edition, Kluwer, Deventer, 2010).

\section{Reehuis 2011}

- W.H.M. Reehuis \& A.H.T. Heisterkamp, Het Nederlands burgerlijk recht: Goederenrecht ( $13^{\text {th }}$ edition, Kluwer, Deventer, 2012).

\section{Rose 2000}

- F.D. Rose, Restitution and Insolvency (Mansfield Press, London, 2000).

\section{Rutgers 1999}

- J.W. Rutgers, International reservation of title clauses: A study of Dutch, French and German Private International Law in the Light of European Law (TMC Asser Press, The Hague, 1999). 
Smits 2011

- J.M. Smits, 'Een Europees privaatrecht als gemend rechtsstelsel, of: naar een ius commune door vrij verkeer van rechtsregels', Nederlands Juristenblad 73 (1998).

Smith 2006

- R.J. Smith, Property Law (5 ${ }^{\text {th }}$ edition, Pearson Education, 2006).

Van Vliet 2011

- L. van Vliet, 'A Factual Assessment of Book VIII of The Draft Common Frame of Reference (Acquisition and Loss of Ownership of Goods)', Maastricht European Private Law Institute Working Paper No. 2011/23.

Wichers 2002

- J.E. Wichers, Natrekking, vermenging en zaaksvorming: Opmerkingen bij de algemene regeling voor roerende zaken in het Burgerlijk Wetboek (Kluwer, Deventer 2002). 